\title{
検体測定室届出薬局における 簡易血液検査の継続を阻害する要因の解明
}

\author{
吉田加奈 ${ }^{\dagger 1}$, 岩田紘樹 ${ }^{\dagger 1,2}$, 小林典子 ${ }^{\dagger 1}$, 藤本和子 ${ }^{1}$, 岡㠃光洋 ${ }^{3,4}$, 山浦克典 ${ }^{* 1,2}$ \\ 慶應義塾大学薬学部 医療薬学・社会連携センター 社会薬学部門 ${ }^{1}$, 慶應義塾大学薬学部附属薬局 ${ }^{2}$ \\ 一般社団法人スマートヘルスケア協会 ${ }^{3}$, 北海道大学大学院保健科学研究院健康イノベーションセンター ${ }^{4}$
}

\section{Disincentives to the Continuation of Self-blood Tests at Community Pharmacies Designated as Bioanalytical Labs}

\author{
Kana Yoshida ${ }^{1}$, Hiroki Iwata, ${ }^{1,2}$, Noriko Kobayashi ${ }^{1}$, Kazuko Fujimoto ${ }^{1}$, \\ Mitsuhiro Okazaki ${ }^{3,4}$ and Katsunori Yamaura ${ }^{* 1,2}$ \\ Division of Social Pharmacy, Center for Social Pharmacy and Pharmaceutical Care Sciences, Faculty of Pharmacy, \\ Keio University ${ }^{1}$, University Community Pharmacy, Keio University ${ }^{2}$, Smart Healthcare Association ${ }^{3}$, \\ Health Innovation \& Technology Center, Fuculty of Health Sciences, Hokkaido University ${ }^{4}$ \\ $\left[\begin{array}{l}\text { Received January 21, } 2016 \\ \text { Accepted May 1, 2016 }\end{array}\right]$
}

In April 2014, the Act on Clinical Laboratory Technicians, etc was revised to allow self-blood tests at community pharmacies designated as "Bioanalytical Labs." However, fewer than 1,000 pharmacies have been designated as such and the number is decreasing. This study aimed to clarify the disincentives to the continuation of pharmacies' participation as Bioanalytical Labs and to contribute to promoting it. We sent a questionnaire to all community pharmacies designated as Bioanalytical Labs. Of the 924 questionnaires distributed, 395 (42.7\%) were returned and 320 were analyzed after excluding incomplete responses. We compared burdens in pharmacy management before and after the start of Bioanalytical Lab operation. The number of "no burden" responses increased after the start of operation $(P=0.002)$. Some burdens such as initial costs for instruments decreased after the start of operation (all $P<0.001)$. More than $90 \%$ of the respondents thought that some points in the guidelines needed revision, and more than $80 \%$ reported that customers had asked them for medical advice, which the guidelines prohibit pharmacists from providing. A significant correlation was found between those who thought that the guidelines needed revision and those who had been asked by customers for medical advice $(P=0.003)$. Our findings indicate that many disincentives that have an impact before the start of operation did not become burdens thereafter. However, many customers asked for medical advice that pharmacists may not provide. It seems necessary to reconsider this aspect of the guidelines in order to suit customers' needs.

Key words — self-blood tests, Bioanalytical Labs, questionnaire, guidelines, disincentive, customers' needs

\section{緒 言}

我が国において生活習慣病患者は増加の一途を たどり，その対策が喫緊の課題となっている（厚 生労働省, 平成 25 年国民健康 - 栄養調査報告, http://www.mhlw.go.jp/bunya/kenkou/eiyou/h25houkoku.html, 2016年6月19日). 2008 年より始まっ
た特定健診は，対象者数に対し受診者数は過去 6 年間でいずれも50\%を切っており（厚生労働省， 平成 25 年度特定健康診査 - 特定保健指導の実施 状況について, http://www.mhlw.go.jp/bunya/shakai hosho/iryouseido01/d1/info03_h25_00.pdf, 2016年 6 月 19 日), 国民の疾病予防, 早期発見に関する意 識は決して高いとはいえない. 超高齢社会を迎え

\footnotetext{
本論文作成に同等に貢献した.

* ×105-8512 東京都港区芝公園1-5-30
} 
た我が国では，国民一人ひとりが自身の健康に関 心をもち, 生活習慣病の予防・早期発見に取り組 む必要がある。

平成 26 年 1 月 20 日に開始されたグレーゾーン 解消制度で, 血液の簡易検查とその結果に基づく 健康関連情報の提供について, 利用者が自己採血 すること，事業者が検査結果の事実を通知するこ とに加え，より詳しい健診を受けるよう勧めるこ とは「医業」に該当しないことが確認された（経 済産業省,「企業単位」の規制改革が進んでいま す!〜「企業実証特例制度」及び「グレーゾーン 解消制度」の活用結果〜, http://www.meti.go.jp/press/ 2013/02/20140226002/20140226002.html, 2016年6月 19日). 次いで平成 26 年 3 月 31 日に臨床検査技師 等に関する法律第二十条の三第一項が改正され, ${ }^{1)}$ 厚生労働大臣が定める施設として新たに「人体か ら採取された検体（受検者が自ら採取したものに 限る.) について生化学的検查を行う施設」（検体 測定室）が追加された.これにより，検体測定室 の届出を申請すれば，薬局でも利用者自身の自己 採血による検体測定が可能になった。

法改正直後は多数の薬局が検体測定室の申請を 行ったものの, 9 カ月後の 2015 年 1 月〜 7 月の新 規届出件数（265 件）と休止-廃止件数（271 件） は拮抗して頭打ちとなり, 現時点で申請薬局数は 1,000 件程度に留まっている．57,000 件を超える 全国の薬局数から考えると（厚生労働省, 平成 27 年度厚生統計要覧, 第 2-84 表 薬局数・無薬局町村 数, 都道府県別, http://www.mhlw.go.jp/toukei/youran/ indexyk_2_4.html, 2016 年 6 月 19 日), 検体測定室 の申請薬局数は $2 \% に も$ 満たない. また, 厚生労 働省が実施した検体測定室の自己点検の結果，お よそ $15 \%$ の薬局が検体測定室のガイドラインを 遵守できていないことが明らかとなった（厚生労 働省医政局地域医療計画課長, 医政地発 0218 第 2 号, 検体測定室の自己点検結果と今後のガイドラ インの運用について, http://www.mhlw.go.jp/file/06Seisakujouhou-10800000-Iseikyoku/0000098577.pdf, 2016 年 6 月 19 日).ただし，ガイドラインによる 規制内容も検体測定室普及の阻害要因となり得 る. グレーゾーン解消制度の運用に際し作成され た「健康寿命延伸産業分野に扔ける新事業活動の
ガイドライン」によると, 民間事業者が利用者に 対して, 検査結果を用いて利用者の健康状態を評 価する等の医学的判断を行ったうえで, 食事や運 動等の生活上の注意, 健康増進に資する地域の関 連施設やサービスの紹介, 利用者からの医薬品に 関する照会に応じた OTC 医薬品の紹介, 健康食 品やサプリメントの紹介, より詳しい健診を受け るように勧めることは違法行為だとされており (厚生労働省・経済産業省, 健康寿命延伸産業分野 における新事業活動のガイドライン, http://www. mhlw.go.jp/seisakunitsuite/bunya/kenkou_iryou/iryou/ kenkoujyumyou/dl/kenkoujyumyou01.pdf, 2016年 6 月 19 日), 明らかな測定值異常を発見し, 利用者に アドバイスを求められたとしても, 薬剤師にでき ることが，結果を伝えることと受診勧奨に制限さ れることも課題の1つだと考えられる.

前述の通り, 検体測定室届出薬局は薬局全体の $2 \%$ に届かず，さらに 2015 年に入って届出の休止 • 廃止件数が増加し, その数は 1 年以上頭打ちの状 態にあるなど，継続において課題を抱えている. そこで本研究では, 検体測定実施薬局の現状を把 握し，継続を阻害する要因を明らかにすることを 目的に, 検体測定室の届出をしている全ての薬局 を対象とする質問紙調査を実施した。

\section{方 法}

\section{1. 調査対象}

2015 年 8 月 5 日現在, 検体測定室の届出を行っ ている全国の 924 薬局全件を調査対象とした。回 答者は, 検体測定室の届出, 測定機器・試薬の購 入, 測定業務の管理に携わっている者が適切と考 え, 薬局の開設者もしくは管理薬剤師とした. 届 出薬局の住所情報は, 検体測定室に関する照会先 である厚生労働省医政局地域医療計画課医療関連 サービス室より提供いただいた。なお，調查期間 は 2015 年 9 月 2 日〜2015 年 9 月 26 日とした。

\section{2. 調査方法}

郵送による無記名自記式質問紙調查を行った。 質問紙には本研究の目的, 質問紙への回答は任意 であること，個人を特定できる情報は収集しない 
検体測定室に関するアンケート

以下の設問の回答に該当する番号を○て围んでたさい。

設問1、検体测定の実施について、貴薬局は以下のどれに当てはまりますか。

1. 現在実施している

2、まだ実施していない

理由

3. 休止または廃止の手続きを行った

理由 (

設問2. 検体測定公を設惪した理由に当てはまるものをお答えください。(複数回答可

菜局の機能拡大のため

2. セルフメディケーションの推准に貢献するため

利用者が見込まれた（恵者からの要望があった）から

4. 梌体测定による利益を期待したから

5. 恵者の堌加につながることを期待したから

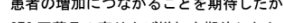

的增加を期したから

7. その他 (

設問了、㛟体測定空の届出を行ったのはいつですか

$$
\text { ) 年( ) 月 }
$$

設問4.これまでの総㨽定件数はおよそ何件ですか。

$$
\text { ( ) 件 }
$$

設問5.そのうち、1 1 項目でも測定值が基準值を外れたのはおよそ何件ですか。

( ) 件

設問6. 測定項目はどれですか。(複数回答可)
1. 血糖值
4. HDL コレステロール
2. HbAlc
5. LDL コレステロール
6. その他 (

設問7、現在の機器で測定できるのは主に糖と脂質ですか、、今後旰機能や腎機能の測定についてはを 几ぞれどう考えますか。

$<$ 肝機能〉

〈腎機能〉

強く関心がある

2. や等閏心がある

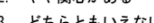

やや関心がある

ビちらともいえない

めまり

あまり関心がない

5. 全く関心がない
設問8、これまでに同一利用者が複数回㛟体測定をするために来局したことはありますか。 ある場合には何人程度いましたか。

1. ある( ) 人

1. かる

設問9.貴薬局にて検体测定を実施していることをどのように周知していますか。(復数回答可)

口頭のみ

、広告（ポスター、チラシなど

3. 近聯の医療機関との連㑺

その他

設問10，届出を行う前に、㛟体測定の実施に関して負担になると予想したことは何ですか。(複数回 答可)

2. 機器設置の経費

5. 测定にかかる時間

3. 標凖作業書な

6. 感染防止対策

7. 人員

9. その他 (

8. スペース

設問11. 検体測定を実施して、負担だと感していることは何ですか。(複数回答可)

ない

5. 測定にかかる時間

2. 機器設置の経費

6. 感染防止対策

標準作業書などの書類の作成・保管

4. 利用者の自己採血にかかる時間

人員

その他

没問12、検体测定を実施する上で利用者にとつてマイナスになると考える要因は何ですか。(復数回 管可)

な

2. 测定にかかる全体の時間

3. 利用者が針を刺すことに対する㯺念（痛み、血が出ること等）

4. その他

設問13、娭体測定を行って良かったと思うことは何ですか。(複数回答可

.なし

疾病の早期発見につながった

利用者とのコミュニケーションのきっかけとなった

かかりつけ菜局・健康相談ステーションとしての活用が增えた

藥局の医療提供施設としての認知度が上がった

6. 菜削師に対する医療人としての認知度が上がった

7. その他 (

設問14、貴薬局での自己採血件数はどのように推移していますか。また、その理由はどのように考え

ていますか。

增加傾问 理由

. 隇少倾向 理由

大きな变化はない 理由

設問15.ガイドライントでやリづらい点、改善ず゙きだと思う点をお答えください。(複数回答可)

2. OTC 薬を勧めてはいけない

3. 生活指導をしてはいけない

利用者から硬康アドバイスを求められた場合も一般論でしか答えてはいけない

その他 (

設問16.これまでに利用者からアドバイスを求められたことはありますか。ある場合はどのような内 容でしたか。(複数回答可)

容でしたか

2. 湕康食品・サフリメントの相談

3. OTC 医薬品の相

4. 生活習慣の相談

5. 健康增進に資する地域の関連施設やサービスの相訬

6. その他 (

アンケートは以上で終わりです。

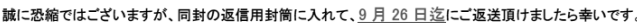
こ協カありがとうごさいました。

図1質問紙 
こと, 本研究の目的以外で用いないことを明記し， 返信をもって研究への参加の同意を得た，質問紙 同様返信用封筒も無記名とした，なお，本研究は 「人を対象とする医学系研究に関する倫理指針」 を遵守し, 慶應義塾大学薬学部 人を対象とする 研究倫理委員会の承認を得て実施した（承認番号 150715-3 平成 27 年 7 月 15 日).

\section{3. 調查項目}

厚生労働省から入手したデータの作成日と調査 開始日とのタイムラグを考慮し，質問紙に検体測 定実施の有無を問う項目を設けた。さらに，検体 測定室設置理由, 届出時期, 総測定件数, 測定項 目，利用者への周知方法，検体測定実施上の負担 要因, 利用者側のデメリット, 薬局側のメリット， ガイドライン上の問題点, 利用者から求められた アドバイス内容を質問項目とした。関心の強さを 尋ねる項目では「1．強く関心がある〜5，全く 関心がない」で回答を得た（図 1).

\section{4. 解析方法}

検体測定実施前後の負担要因の変化は, McNemar's test を用い解析した。 また，ガイドラ イン上に関する問題点と利用者からのアドバイス 要求の有無の関連性の解析には, $\chi^{2}$ 検定を用いた. 設問 5, 6 は未回答者が多く, 解析対象から外し た（図 1)。解析には $\mathrm{IBM}^{\circledR}$ SPSS $^{\circledR}$ Statistics 22 (日 本 IBM（株），東京）を使用した。

\section{結 果}

得られた回答は 395 件（回収率 $42.7 \%$ ）であっ た。このうち，検体測定室の届出はしたが測定実 施件数 0 の薬局と, 設問に対し 1 つ以上の久損デー
夕のある薬局を合わせた 75 件を除外した 320 件 を有効回答として解析した（有効回答率 $81.0 \%$ ).

解析対象薬局のうち, 現在検体測定を実施して いる薬局は 311 件，休止または廃止している薬局 が9件あった。休止または廃止した薬局について は，休止または廃止した時期が質問項目になく正 確な実施期間が把握できないため, 実施期間と総 測定件数については現在検体測定を実施している 薬局 311 件のみのデー夕を示した（表 1）。実施 期間は 7〜12 カ月間が最も多く（154 件），13〜 19 力月間（111 件），1６力月間（44 件）と続 いた。また，総測定件数は 10 件以下が最も多く 123 件（40\%）であり，51 件以上測定している 薬局は 54 件（20\%）に満たなかった（表 1).

検体測定室を設置した理由として，「セルフメ デイケーションの推進に貢献するため」が $83.8 \%$ (268 件),「薬局の機能拡大のため」が 70.3\%（225 件）であった。検体測定による利益を期待」「医 薬品の売り上げ増加を期待」などの金銭的利益を 期待する薬局はいずれも $10 \%$ に満たなかった. 「その他」の自由記述としては「県薬郕師会の意向」 「研究のため」などが挙げられた（図 2).

血中脂質・糖質以外の測定項目として, 肝およ び腎機能測定に対する関心の強さを 5 段階で尋ね たところ，「強く関心がある」「やや関心がある」 の合計が $70 \%$ を超え, 関心の高さが明らかとなっ た。また，肝および腎機能検查の間に明らかな差 は見られなかった（data not shown）。

検体測定室の負担要因に関しては，実施前と実 施後で同じ質問項目を設定し，それぞれ回答を得 た．実施前後で比較したところ，「負担なし」と 回答した薬局数が有意に増加した $(P=0.002)$. 「ス ペース」,「機器設置経費」,「感染防止対策」,「標 準作業書などの書類の作成・保管」は実施前には

表 1 検体測定実施期間および総測定件数別にみた解析対象薬局数 $(\mathrm{n}=311)$

\begin{tabular}{|c|c|c|c|c|c|c|c|c|}
\hline \multirow{2}{*}{ 実施期間 } & \multicolumn{7}{|c|}{ 総測定件数 } & \multirow{2}{*}{ 合計 } \\
\hline & $1 \sim 10$ & $11 \sim 20$ & $21 \sim 30$ & $31 \sim 40$ & $41 \sim 50$ & $51 \sim 100$ & $101 \sim$ & \\
\hline $1 \sim 6$ 力月 & 21 & 11 & 6 & 5 & 1 & 0 & 0 & 44 \\
\hline $7 \sim 12$ 力月 & 77 & 36 & 11 & 7 & 5 & 12 & 6 & 154 \\
\hline 13〜19 カ月 & 25 & 21 & 12 & 7 & 11 & 18 & 17 & 111 \\
\hline 20 力月以上 & 0 & 0 & 1 & 0 & 0 & 0 & 1 & 2 \\
\hline 合計 & 123 & 68 & 30 & 19 & 17 & 30 & 24 & 311 \\
\hline
\end{tabular}




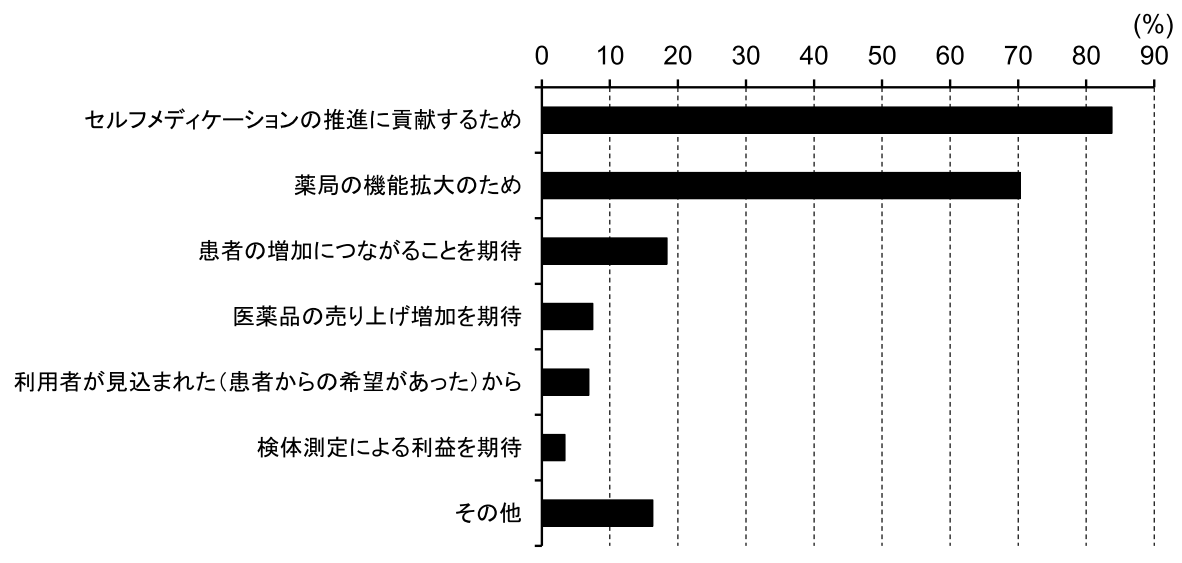

図 2 検体測定室の設置理由（複数回答可）（ $\mathrm{n}=320 ）$

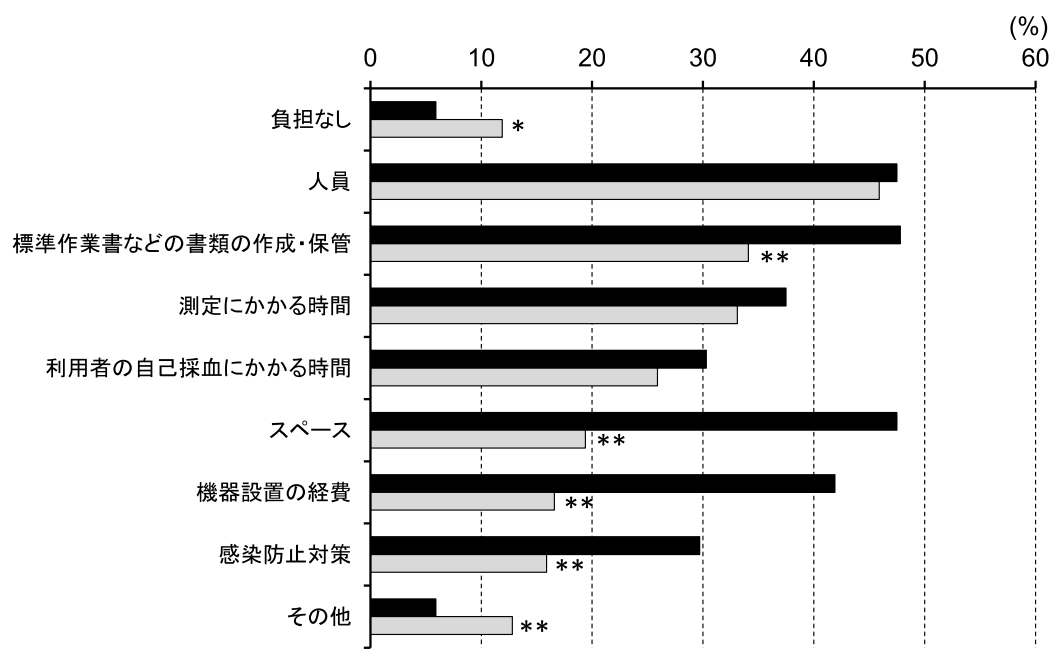

図 3 検体測定室の負担要因に関する実施前後の比較（複数回答可）（n=320）

口実施前， $\square$ 実施後. $* P<0.01, * * P<0.001$ vs 実施前 (McNemar's test)

負担に感じていた薬局が多かったものの，実施後 に有意に減少した $(P<0.001)$ 。一方,「人員」,「測 定にかかる時間」，「利用者の自己採血にかかる時 間」はいずれも実施前後で大きな変化は見られな かった（図3）。また，「その他」の自由記述では, 実施前後にかかわらず「医師会との関係」などが 挙げられており，実施後に増加した負担要因とし て「試薬ディスクの費用・期限」，「説明にかかる 時間」などが挙げられた（data not shown）.

「検体測定を行って良かったと思うこと」を尋 ねたところ，「なし」と回答した薬局は 6.6\%（21 件）のみで，9割以上の薬局が検体測定を実施し て良かったと考えていた，最も多かったのは「利 用者とのコミュニケーションのきっかけとなっ た」の 68.8\% (220 件), 次いで「かかりつけ薬局・ 健康相談ステーションとしての活用が増えた」が
49.7\%（159 件）であった（図 4).

「ガイドライン上でやりづらい点, 改善すべき 点」に関する設問に対し,「なし」との回答は $9.7 \%$ （31 件）に留まり，9割以上の回答者がガイドラ インに対しやりづらさを感じていることが明らか となった。特に多かったのは「利用者から健康ア ドバイスを求められた場合も一般論でしか答えて はいけない」の $71.3 \%$ （228 件),「生活指導して はいけない」の 64.7\%（207 件）であった（図 $5 A$ ).「その他」の自由記述では, 「利用者の採血 を手伝ってはいけない」ことを多くの薬局がやり づらい点として挙げていた (data not shown). 利 用者の求めに対してアドバイスするとガイドライ ン上違法行為とされる項目について,「利用者か らアドバイスを求められた経験」を尋ねたところ, 「生活習慣の相談」が 75.9\% (243 件), 次いで「健 


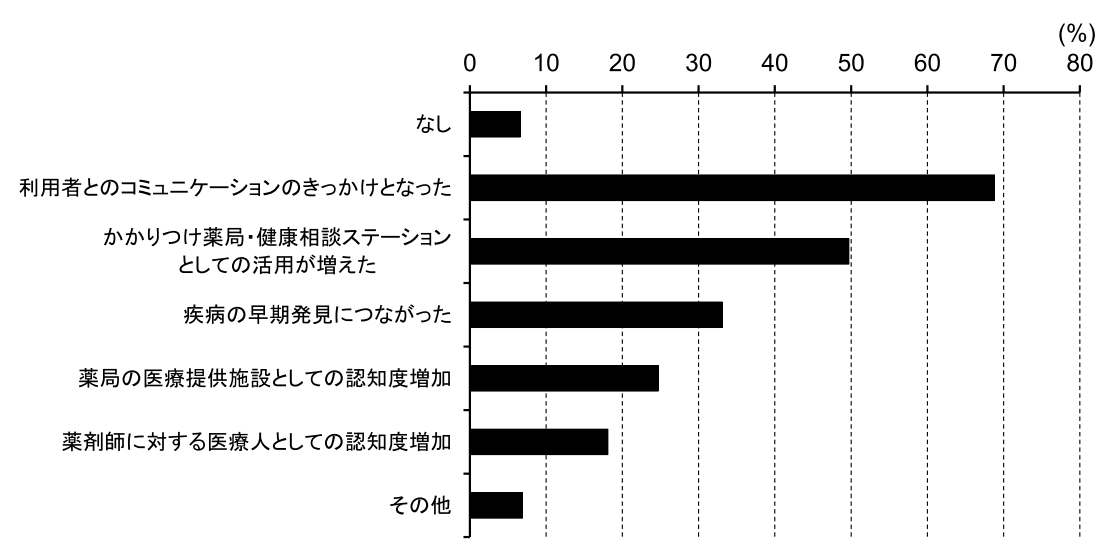

図 4 検体測定を行って良かったと思うこと（複数回答可）（n=320）

(A)

利用者から健康アドバイスを求められた場合も 一般論でしか答えてスをいけない

生活指導してはいけない

OTC薬を勧めてはいけない

その他

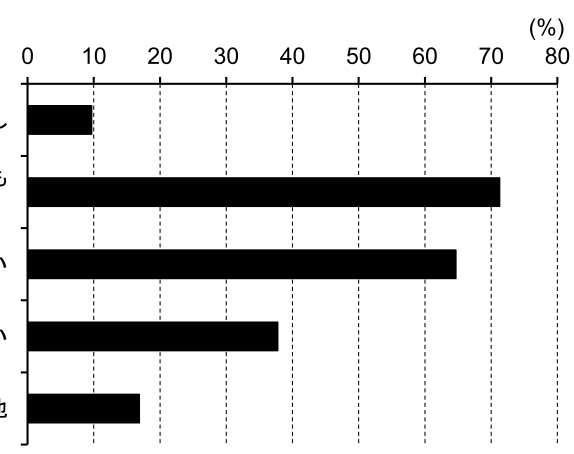

(B)

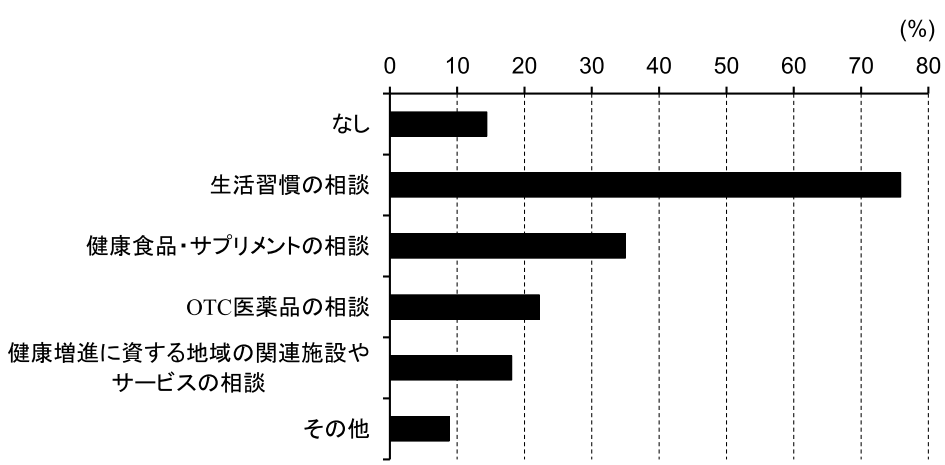

図 5 ガイドライン上のやりづらさと利用者が求めるアドバイス $(\mathrm{n}=320)$ (A) ガイドライン上でやりづらい点, 改善すべき点.（B）利用者から求められたアド バイスの内容.

康食品・サプリメントの相談」が $35.0 \%$ （112 件） であった (図 5B).「ガイドライン上でやりづら い点, 改善すべき点」の有無 $($ 有 $=289$, 無 $=31)$ と, 「利用者から求められたアドバイス」の有無（有 $=274$, 無 = 46）に関し， $\chi^{2}$ 検定を行ったところ， 有意な関連性が認められた $(P<0.01)$.これより， 利用者からアドバイスを求められた経験のある薬 局は，ガイドライン上やりづらさを感じ，改善す ベき点があると考えていることが明らかとなった。

\section{考察}

本研究は，検体測定室の届出をしている施設を 対象とした初めての調査研究である.

まず，検体測定室設置の理由として，ほとんど の薬局が利益目的ではなく, セルフメディケー ションの推進に貢献するなど, 国民の健康増進に 寄与することを目的として設置していた。また， 現在検体測定用の機器で測定できるのは主に血 糖，脂質に関する項目だけであるが，肝および腎 
機能の測定にも関心が高いことが明らかとなっ た．現段階では検体測定の主な目的は生活習慣病 の予防となるが，今後肝および腎機能に関する項 目の測定が可能となれば，処方薬や OTCによる 副作用の早期発見にも貢献できるため, 機器メー カーの開発が待たれる。これは「薬局・薬剂師を 活用した健康情報拠点推進事業」を実践する「健 康サポート薬局」が果たすべき役割にも合致する。

一方で，上記事業推進の一環として検体測定を 実施するには難点も存在する. 現行のガイドライ ンの制約により, 検体測定を行っても薬剤師がで きることは，結果を伝え定期健診等の受診勧奨を することに留まる，今回の調査では，検体測定を 行っている薬局の 8 割以上が, 利用者からガイド ライン上違法行為とされる項目についてアドバイ スを求められており，利用者は結果を踏まえた薬 剤師のアドバイスを必要としていた。平成 27 年 度に実施された「薬局の機能に関わる実態調査」 の結果では, 患者が薬局に求める機能として,「気 軽に健康相談を受けられること」ままた患者が薬 剂師をかかりつけ薬郕師とする理由は，「薬に限 らず何でも相談に乗ってくれるから」の回答が多 く, 本研究で明らかとなった患者のニーズとも一 致する（中央社会保険医療協議会, 調剤報酬（そ の 2), 中医協 総-1 (27.12.4), http://www.mhlw.go. jp/file/05-Shingikai-12404000-Hokenkyoku-Iryouka/ 0000106118.pdf, 2016 年 6 月 19 日).また, 薬局側 としても 9 割以上が現行のガイドラインにやりづ らい点, 改善すべき点があると回答し, 利用者か らアドバイスを求められたとする回答との間に関 連性が確認された。このことから, 利用者のニー ズを把握しているにもかかわらず，ガイドライン の制約によりそれに応えられないことが検体測定 の継続における阻害要因の一部となっている可能 性が考えられた。これを結論付けるには，さらに 検体測定室の届出を取り下げた薬局を対象とした 調查研究が必要である.

検体測定室の負担要因のうち, 標準作業書など 書類の作成・保管, 機器設置の経費, 感染防止対 策，スペースの 4 要因に関しては，検体測定実施 後に負担と感じる件数が有意に減少することが明 らかとなった。本研究結果を現在検体測定室の届
出を迷っている薬局に示すことで, 普及の阻害要 因を軽減できると思われる。一方，人員や時間に 関する課題に対しては，何らかの対策が必要と考 える. 人員に関しては, 薬剤師数の増員で対応す ることは困難であり, 予約制や曜日指定などの導 入が考えられる。また，時間に関してだが，利用 者の自己採血にかかる時間は，利用者が穿刺をた めらったり，失敗による再度採血などが時間がか かる要因として挙げられるが, 現行のガイドライ ンでは利用者の採血穿刺および血液の絞り出しを 手伝うことはできない（厚生労働省医政局地域医 療計画課, 検体測定室における一連の採血行為で の医行為に該当する部分について, http://www. nichiyaku.or.jp/action/wp-content/uploads/2015/08/ saiketsu.pdf, 2016 年 6 月 19 日). 手技が苦手な利用 者に依頼されたり，高齢者で手元が見づらいなど の理由により利用者の求めがあった場合に限り, 例外規定として薬剤師が手伝うことを可能とする などの緩和が望まれる。一方, 測定にかかる時間 は, 機器や測定項目に依存するものの, 現行の測 定機器では最長 10 分程度かかるため, 機器メー カー側の時短努力に期待したい.

本研究の限界として, 調査対象を検体測定室の 届出薬局としたことで, 検体測定に前向きな意見 に偏っている可能性がある. 今後, 検体測定室の 届出を行っていない薬局を調査対象に加え, 普及 の阻害要因を比較検討する必要があると考える.

\section{謝 辞}

本研究の実施にあたり, 質問紙調查にご協力い ただきました薬局の皆様に深くお礼申し上げます。

\section{利益相反}

開示すべき利益相反はない.

\section{引用文献}

1）厚生労働省告示, 臨床検查技師等に関する法律 第二十条の三第一項の規定に基づき厚生労働大 臣が定める施設の一部を改正する件（厚生労働 一五六). 官報, 2014, 号外70, 272. 